Article

\title{
Investigation of the Possible Pharmacologically Active Forms of the Nicotinic Acetylcholine Receptor Agonist Anabaseine
}

\author{
Kristin Andrud ${ }^{1, \dagger}$, Hong Xing ${ }^{1, \dagger}$, Bjarne Gabrielsen ${ }^{2}$, Linda Bloom ${ }^{3}$, Vladimir Mahnir ${ }^{1}$, \\ Stephen Lee ${ }^{4}$, Benedict T. Green ${ }^{4}$, Jon Lindstrom ${ }^{5}$ and William Kem ${ }^{1, *}$ \\ 1 Department of Pharmacology and Therapeutics, College of Medicine, University of Florida, Gainesville, \\ FL 32610, USA; Kristin.Andrud@du.edu (K.A.); hong.xing@ufl.edu (H.X.); \\ wrkem@pharmacology.lufl.edu (V.M.) \\ 2 Department of Chemistry, University of Florida, Gainesville, FL 32610, USA; bmlmpunta@yahoo.com \\ 3 Department of Biochemistry and Molecular Biology, College of Medicine, University of Florida, Gainesville, \\ FL 32610; USA; lbloom@ufl.edu \\ 4 USDA-ARS Poisonous Plant Research Laboratory, Logan, UT 84341, USA; Stephen.Lee@ars.usda.gov (S.L.); \\ Ben.Green@ars.usda.gov (B.T.G.) \\ 5 Department of Neuroscience, University of Pennsylvania, Philadelphia, PA 19104, USA; \\ jslkk@mail.med.upenn.edu \\ * Correspondence: wrkem@ufl.edu; Tel.: +1-352-392-0669 \\ + Denotes first authors.
}

Received: 23 August 2019; Accepted: 24 October 2019; Published: 29 October 2019

\begin{abstract}
Three major forms of the nicotinic agonist toxin anabaseine (cyclic iminium, cyclic imine and the monocationic open-chain ammonium-ketone) co-exist in almost equal concentrations at physiological $\mathrm{pH}$. We asked the question: Which of these forms is pharmacologically active? First, we investigated the $\mathrm{pH}$ dependence of anabaseine inhibition of $\left[{ }^{3} \mathrm{H}\right]$-methylcarbamylcholine binding at rat brain $\alpha 4 \beta 2$ nicotinic acetylcholine receptors (nAChRs). These experiments indicated that one or both monocationic forms interact with the orthosteric binding site for ACh. However, since they occur at equal concentrations near physiological $\mathrm{pH}$, we employed another approach, preparing a stable analog of each form and examining its agonist activities and binding affinities at several vertebrate brain and neuromuscular nAChRs. Only 2-(3-pyridyl)-1,4,5,6-tetrahydropyrimidine monohydrogen chloride (PTHP), the cyclic iminium analog, displayed $\mathrm{nAChR}$ potencies and binding affinities similar to anabaseine. The cyclic imine analog 2,3'-bipyridyl and the open-chain ammonium-ketone analog 5-methylamino-1-(3-pyridyl)-1-pentanone (MAPP), displayed $\leq 1 \%$ of the activity predicted if the one form was solely active. The lower potency of weakly basic $2,3^{\prime}$-bipyridyl can be explained by the presence of a small concentration of its monocationic form. Since the open chain ammonium-ketone monocationic form of anabaseine has some structural similarity to the neurotransmitter GABA, we also tested the ability of anabaseine and its 1,2-dehydropyrrolidinyl analog myosmine to activate a mammalian $\mathrm{GABA}_{\mathrm{A}}$ receptor, but no activity was detected. We conclude that the monocationic cyclic iminium is the form which avidly binds and activates vertebrate nAChRs.
\end{abstract}

Keywords: acetylcholine; alkaloid; anabaseine; bipyridyl; cholinergic; nicotine; nicotinic acetylcholine receptor; ring-chain tautomerism; toxin

\section{Introduction}

Over eighty years ago, the Belgian pharmacologist Z. M. Bacq discovered the presence of a nicotine-like substance in a marine worm, the Atlantic hoplonemertine Amphiporus lactifloreus [1,2]. 
Small amounts of a weakly basic compound(s), called "amphiporine", were partially purified using classical solvent extraction methods, but isolation by crystallization with standard alkaloid precipitating salts like picric acid was unsuccessful [3]. Anabaseine, an alkaloid with chemical and pharmacological properties similar to nicotine, was eventually isolated from the Pacific hoplonemertine Paranemertes peregina and detected in A. lactifloreus [4-6]. A piperideine analog of the tobacco alkaloid anabaseine, anabaseine also occurs in certain ants [7]. It is a potent agonist at a variety of nicotinic acetylcholine receptors, particularly the vertebrate skeletal muscle and $\alpha 7$ neuronal nAChRs that display high affinities for the snake toxin $\alpha$-bungarotoxin. Anabaseine is also a weak partial agonist at $\alpha 4 \beta 2 \mathrm{nAChRs}$ that modulate cognitive and addiction neuronal circuits in the brain [8].

The imine bond of anabaseine, besides increasing its interaction with certain nAChRs, has enabled this molecule to serve as a useful "lead" compound for designing drug candidates that target $\alpha 7$ nAChRs [9-11]. 3-(2,4-dimethoxybenzylidene)anabaseine (also called DMXBA and GTS-21), the most studied anabaseine drug candidate, enhances cognition in humans [12,13], reduces inflammation [14], inhibits skeletal muscle wasting [15,16] and is neuroprotective in Parkinson's [17] and Alzheimer's disease [18] animal models. New anabaseine compounds that are more potent and selective $\alpha 7 \mathrm{nAChR}$ agonists have been reported $[19,20]$.

Most nAChR agonists and competitive antagonists possess a cationic moiety that tightly binds within an electronegative "aromatic box" of the receptor formed by five aromatic amino acid side chains [21,22]. The dominant role of the monocationic form of nicotine has been demonstrated by experiments where the $\mathrm{pH}$ bathing intact skeletal muscle cells is varied [23-25]. Such an experimental approach assumes that altering $\mathrm{pH}$ mainly affects ionization of the ligand, rather than that of the nAChR. Subsequently several laboratories reported myriad effects of $\mathrm{pH}$ on several $\mathrm{nAChR}$ subtypes [26,27]. Altering extracellular $\mathrm{pH}$ was also found to affect muscle chloride permeability and resting membrane resistance, which indirectly affect response to nicotinic agonists $[28,29]$.

Whereas anabaseine contains a moderately basic (pKa 8.7, [30]) secondary amine group and mainly exists as a monocation at physiological $\mathrm{pH}$, cyclic anabaseine contains a tertiary amine group but exists in three different chemical forms at neutral $\mathrm{pH}$ (Figure 1): the unionized cyclic imine (I), cationic cyclic iminium $\left(\mathrm{I}^{+}\right)$and monocationic open-chain ammonium ketone $\left(\mathrm{AK}^{+}\right)$forms are in dynamic equilibrium at approximately equal concentrations at $\mathrm{pH} 7.4$ [31,32]. Our initial experiments on the $\mathrm{pH}$ dependence of anabaseine interaction with a brain $\mathrm{nAChR}$, presented below, suggest that one or both monocationic forms are most active. However, since the two monocationic forms coexist at equal concentrations regardless of $\mathrm{pH}$, a different experimental approach to assess their separate activities was required. Thus, we prepared a stable analog for each form and studied its effects on several vertebrate nAChRs: two fetal-type skeletal muscle (electric fish and human TE671 myosarcoma) receptors and the two major brain subtypes, $\alpha 4 \beta 2$ and $\alpha 7$. Since the open chain ammonium ketone cationic forms of anabaseine and its five-membered ring analog myosmine have some resemblance to another neurotransmitter, $\gamma$-aminobutyric acid (GABA), we also investigated whether anabaseine and its myosmine can activate a $\mathrm{GABA}_{\mathrm{A}}$ receptor. 
$\mathbf{A}$<smiles>C=C=C</smiles>

Open-chain Ammonium-Ketone<smiles>c1cncc(C2=[NH+]CCCC2)c1</smiles>

Cyclic Iminium<smiles>C#CC=Cc1cccnc1</smiles>

Cyclic Imine

B<smiles>C[NH+]([IH+])CCCCC(=O)c1cccnc1</smiles>

MAPP

5-Methylamino-1-(3-pyridyl)-

1-pentanone<smiles>c1cncc(C2=[NH+]CCCN2)c1</smiles>

PTHP<smiles>c1ccc(-c2cccnc2)nc1</smiles>

2,3'-Bipyridyl

2-(3-Pyridyl)-1,4,5,6tetrahydropyrimidine

Figure 1. A: Structures of the three major forms of anabaseine that exist in dynamic equilibrium under physiological conditions; B: Anabaseine analogs synthesized to represent the particular form shown above. MAPP (also called $N$-methyl anabaseine) can still occur as a cyclic imine or iminium, but the equilibrium greatly ( $\geq 20$-fold) favors the ammonium-ketone monocation form.

\section{Results}

Initially, we measured the $\mathrm{pH}$-dependent binding of $\left[{ }^{3} \mathrm{H}\right]$-methylcarbamylcholine $\left(\left[{ }^{3} \mathrm{H}\right]-\mathrm{MCC}\right)$ to rat brain $\alpha 4 \beta 2 \mathrm{nAChRs}$. In the absence of anabaseine we found a large (approximately 3 -fold) enhancement of $\left[{ }^{3} \mathrm{H}\right]-\mathrm{MCC}$ binding as $\mathrm{pH}$ increased from 6.0 to 7.8. While interesting in its own regard, since MCC is permanently ionized, this marked $\mathrm{pH}$ dependence of $\left[{ }^{3} \mathrm{H}\right]-\mathrm{MCC}$ nAChR affinity complicated the analysis of the effect of $\mathrm{pH}$ on anabaseine binding, which was indirectly measured by $\left[{ }^{3} \mathrm{H}\right]-\mathrm{MCC}$ displacement. Anabaseine inhibition of $\left[{ }^{3} \mathrm{H}\right]-\mathrm{MCC}$ binding at each $\mathrm{pH}$ in Figure 2 is expressed with respect to the binding of $\left[{ }^{3} \mathrm{H}\right]-\mathrm{MCC}$ alone at the same $\mathrm{pH}$, so as to compensate for $\left[{ }^{3} \mathrm{H}\right]-\mathrm{MCC}$ binding $\mathrm{pH}$ dependence. If only one or both monocationic forms of anabaseine are active, one would anticipate that inhibition of $\left[{ }^{3} \mathrm{H}\right]-\mathrm{MCC}$ binding by the fixed concentration of anabaseine would be greatest at the low $\mathrm{pHs}$ and progressively decrease as the $\mathrm{pH}$ approaches and exceeds the pKa of its tertiary amine (iminium) group. However, if only the cyclic imine form binds with high affinity one would expect the opposite effect, an increase in the inhibition of $\left[{ }^{3} \mathrm{H}\right]-\mathrm{MCC}$ binding as the $\mathrm{pH}$ approaches and exceeds the tertiary amine pKa. Anabaseine displacement of $\left[{ }^{3} \mathrm{H}\right]-\mathrm{MCC}$ binding did decrease with increased $\mathrm{pH}$, as expected for an active monocationic form, but the decrease was quantitatively less than would be predicted. Going from 5.8 to 7.8 , the unionized cyclic imine (I) concentration was predicted [31] to increase approximately 20-fold, but the concentration of each monocationic form $\left(\mathrm{I}^{+}\right.$or $\left.\mathrm{AK}^{+}\right)$would decrease $\sim 4$-fold. The $\mathrm{pH}$ dependence of anabaseine inhibition of MCC binding was not as marked as predicted for the monocationic form, but was certainly more consistent with the hypothesis that one or more monocationic forms of anabaseine is binding to this brain receptor. One additional complication in the interpretation of the results in Figure 2 is that specific receptor binding (and its inhibition) is not necessarily proportional to the displacing ligand (anabaseine) concentration, as it depends on a saturable binding isotherm (For instance, a Michaelis-Menton equation relating competing ligand concentrations and their respective equilibrium dissociation constants, 
which may not have the same $\mathrm{pH}$ dependence. The concentration of $\left[{ }^{3} \mathrm{H}\right]-\mathrm{MCC}$ was $10 \mathrm{nM}$, which was almost the same as the $K_{d}(11 \mathrm{nM})$ of this radioligand with rat brain membranes, under our experimental conditions [5].

Since the two monocationic forms show the same $\mathrm{pH}$ dependence and the same concentration when expressed as \% of total anabaseine, another approach was required to assess their activities separately. We resorted to synthesizing and testing stable analogs that resemble the three anabaseine forms. PTHP, the tetrahydropyrimidinyl analog of the cyclic iminium form, is predicted to be $>99 \%$ ionized at $\mathrm{pH} 7.4$ and does not undergo ring opening within the physiological $\mathrm{pH}$ range considered here, since the basic $\left(\mathrm{pK}_{\mathrm{a}}>10\right)$ amidinium group, unlike the imine group, is not susceptible to hydration and subsequent ring opening. 2,3'-bipyridyl $\left(\mathrm{pK}_{\mathrm{a}} 4.4\right)$ was selected as an analog that possesses the basic structure of the unionized cyclic imine; at $\mathrm{pH} 7.4>99.9 \%$ of the molecules of $2,3^{\prime}$-bipyridyl will be unionized. The monocationic ammonium-ketone open-chain form analog selected was 5-methylamino-1-(3-pyridyl)-1-pentanone, MAPP, shown in Figure 1; it mainly ( $>99 \%)$ exists in their open-chain form in water at physiological $\mathrm{pH}$; its cyclic imine or iminium form, $\mathrm{N}$-methylanabaseine, is present in very small concentration $(\leq 5 \%)$ [31-33]. An unionized open-chain amino-ketone form which occurs at high pHs [32] can be neglected due to its very small predicted concentrations over the $\mathrm{pH}$ range 5.8 to 7.8 that is of interest here.

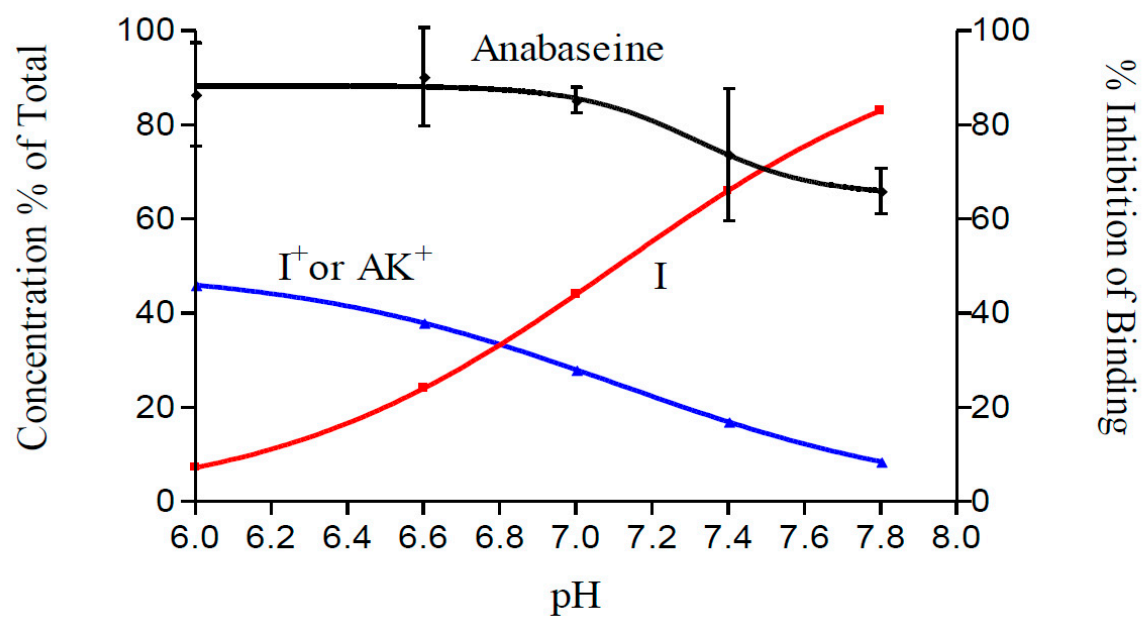

Figure 2. Concentrations of the three major forms of anabaseine as a function of $\mathrm{pH}$ as determined by UV spectrophotometry [32]. Left Ordinate: Concentration of each form expressed as \% of the total anabaseine concentration. The red curve is the estimated cyclic imine concentration and the blue curve is the concentration of the cyclic iminium or the monocationic ammonium-ketone form of anabaseine (Assuming that $\mathrm{K}_{\mathrm{H}}=1.0$, the concentrations of these ionized forms are equal). Right ordinate: $\mathrm{pH}$ dependence of anabaseine inhibition of $\left[{ }^{3} \mathrm{H}\right]-\mathrm{MCC}$ binding to rat brain $\alpha 4 \beta 2$ receptors (Standard error bars included). Anabaseine inhibition (mean $\pm \mathrm{SEM}$ ) at each $\mathrm{pH}$ was the average of six replicate measurements.

PTHP was the only anabaseine analog that approached anabaseine in potency and binding affinity. Its potency and affinity for both the frog and human neuromuscular receptors was slightly inferior to that of anabaseine, but its agonist activity on vertebrate nAChRs had not been reported (Please see Figures 3 and 4). The other analogs displayed less than $1 \%$ of anabaseine's potency and binding affinity. The small potency of 2,3'-bipyridyl can be interpreted as being entirely due to its monocationic form, since the $\mathrm{pKa}$ of the most basic nitrogen on the 2 'pyridyl ring is 4.4 [34]. 

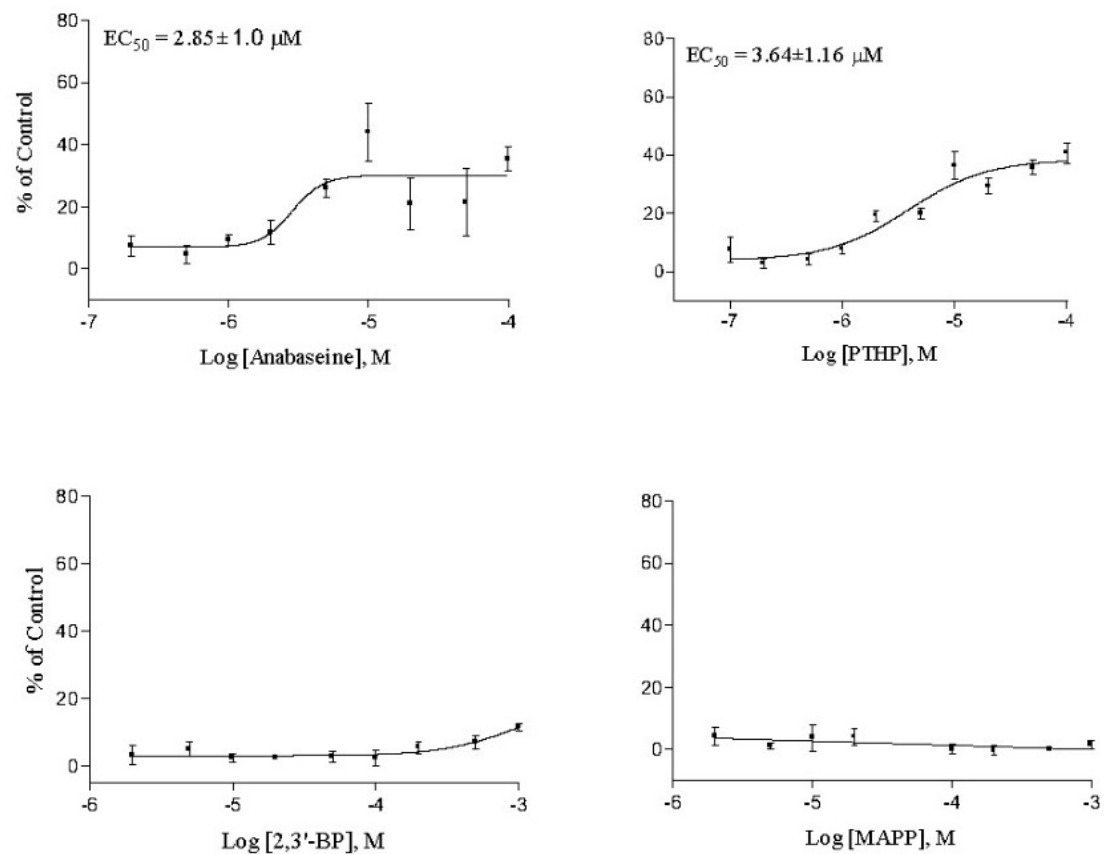

Figure 3. Activation of the human $\alpha 4 \beta 2$ neuronal nAChR expressed in ts $A 201$ cells as measured by membrane depolarization using the FlexStation assay. Each point generally is the mean of four separate measurements. All responses were normalized with respect to the response of the cells to $0.5 \mu \mathrm{M}$ epibatidine. Potency and efficacy estimates from these curves are found in Table 1.
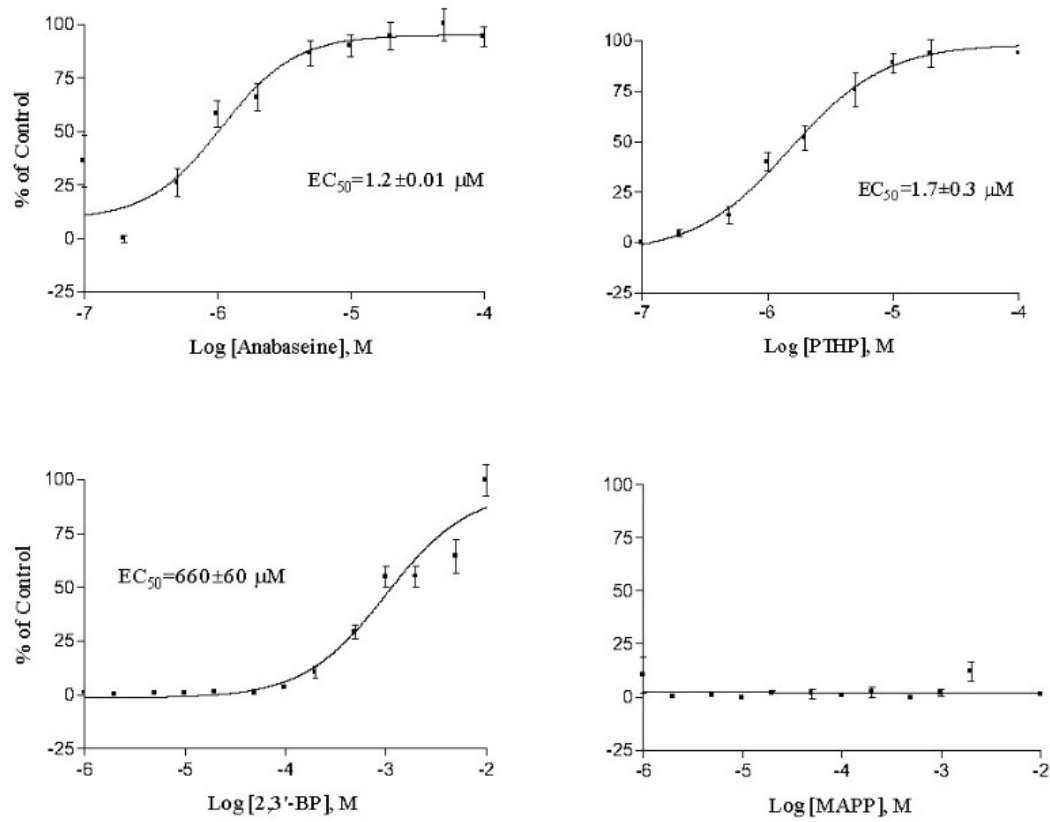

Figure 4. Activation of the human fetal (TE671 cells) skeletal muscle nAChR by the various stable anabaseine analogs measured by membrane depolarization using the FlexStation assay. Each point is generally the mean of four separate measurements. Responses were normalized to the $5 \mu \mathrm{M}$ epibatidine response. Potency and efficacy estimates from these curves are found in Table 1.

$\mathrm{GABA}_{\mathrm{A}}$ receptors are homologous structures that have a common ancestry with nAChRs. Structure-activity studies on $\mathrm{GABA}_{\mathrm{A}}$ receptors have shown that both the ammonium and carboxy groups are not absolutely required for agonist activity and the intermediate structure between these two ionizable groups can vary considerably as well-in some cases flexibility is minimized by a ring structure, such as in the agonist muscimol, and in other analogs the hydrocarbon chain is shortened or 
lengthened one methylene unit without loss of agonist activity. Since the open-chain cationic form of anabaseine resembles GABA by having a primary ammonium group that is separated a similar distance from a carbonyl group, we tested anabaseine and its pyrroline homolog myosmine on a human $\mathrm{GABA}_{\mathrm{A}}$ receptor heterologously expressed in a HEK cell line [35]. Figure 5 shows that anabaseine and myosmine are not $\mathrm{GABA}_{\mathrm{A}}$ agonists, at least on this particular $\mathrm{GABA}_{\mathrm{A}}$ receptor subtype.

Table 1. Potencies and affinities characterizing the interactions of anabaseine and its stable analogs with several neuronal and neuromuscular nAChRs.

\begin{tabular}{cccccc}
\hline & \multicolumn{3}{c}{ Neuronal nAChR } & \multicolumn{2}{c}{ Neuromuscular nAChR } \\
\hline & Human & Rat & Rat & Human & Torpedo \\
Compound & $\alpha 4 \beta 2$ & $\alpha 4 \beta$ & $\alpha 7$ & TE671 & Electric Organ \\
$\mu \mathrm{M}:$ & $\mathrm{EC}_{50}$ & $\mathrm{~K}_{\mathrm{i}}{ }^{1}$ & $\mathrm{~K}_{\mathrm{i}}{ }^{2}$ & $\mathrm{EC}_{50}$ & $\mathrm{IC}_{50}{ }^{3}$ \\
\hline Anabaseine & $2.85 \pm 1.0$ & $0.096 \pm 0.01$ & $1.87 \pm 0.10$ & $1.2 \pm 0.0$ & $0.29 \pm 0.18$ \\
PTHP & $3.64 \pm 1.2$ & $0.38 \pm 0.07$ & $1.54 \pm 0.76$ & $1.7 \pm 0.3$ & $0.47 \pm 0.01$ \\
$2,3^{\prime}$-Bipyridyl & $>1000$ & $>50$ & $>2300$ & $660 \pm 60$ & $343 \pm 48$ \\
MAPP & $>2000$ & 10 & $>2000$ & $>1000$ & $>500$
\end{tabular}

${ }^{1}$ Determined by displacement of $\left[{ }^{3} \mathrm{H}\right]$-cytisine; ${ }^{2}$ Determined by displacement of $\left[{ }^{125} \mathrm{I}\right] \alpha$-bungarotoxin; ${ }^{3}$ Determined by inhibition of the rate of binding of $\left[{ }^{125} \mathrm{I}\right]-\alpha$-bungarotoxin.

\section{Discussion}

While most nAChR agonists and antagonists binding at ACh orthosteric sites are basic molecules with at least one ionizable $\mathrm{N}$, there are exceptions, including lophotoxin [36], the neonicotinoids [37,38] and some recently synthesized pyrimidine agonists [39]. To optimize a molecule to serve as a drug or selective molecular probe of some receptor it is important to identify the form in which it interacts optimally with its target. In the case of anabaseine, our identification of the cyclic iminium form as the most active (and possibly the only) form suggests that structural modifications that enhance the basicity of its tetrahydropyridyl nitrogen will enhance potency and possibly selectivity for the intended receptor target. In fact, a major improvement in stability occurs with addition at the 3-position of the tetrahydropyridyl ring of an electron-conjugated system containing an aromatic ring, as in 3-(4-dimethylaminobenzylidene)-anabaseine [40] or 3-(2,4-dimethoxybenzylidene)-anabaseine, also called GTS-21 [41]. These anabaseine derivatives do not undergo ring opening (hydrolysis of the imine bond) under physiological conditions, due to their extended $\pi$ electron conjugation [42].

Previously, it was assumed (but not experimentally tested) that the cyclic iminium form of anabaseine is the one which binds avidly to the ACh binding site in nAChRs [8]. This form was modeled to fit into a muscle type homology model [43]. The crystal structure of the molluscan acetylcholine binding protein binding anabaseine [44] actually was derived from crystals containing both the cyclic iminium and the open-chain monocationic form of anabaseine occupying some of the five identical binding sites. Unlike the cyclic iminium, the ammonium-ketone form ammonium group did not insert into the "aromatic box." In the preparation of the AChBP-anabaseine crystals very high anabaseine concentrations were used so that most of the five sites would be occupied; therefore the presence of the ammonium-ketone form in the crystal structure does not necessarily indicate that this form of anabaseine would bind to AChBPs and nAChRs at the low concentrations of anabaseine that occur in our in vitro functional and binding studies.

The ability of a variety of 2-(aryl)-1,4,5,6-tetrahydropyrmidines to block neuromuscular nAChRs and produce teratogenic effects in chick embryos was reported long ago [45,46]. Some of these compounds were reported to be nAChR agonists. The only study of PTHP on neurons was that of Upshall et al. [47] on leech Retzius cells. Our results also indicate that PTHP is a potent agonist at neuronal as well as neuromuscular nAChRs. The 2-aryl compounds reported in the Brimblecombe et al. study did not include PTHP or other compounds having a 2-(3-pyridyl)- substituent, which is known to be essential for the agonist activity of nicotine and of anabaseine. For PTHP to be equipotent 
with anabaseine, based on the $\mathrm{I}^{+}$form being the only active form, its $\mathrm{EC}_{50}$ would need to be $\sim 1 / 3$ of the $\mathrm{EC}_{50}$ of anabaseine, since the anabaseine $\left(\mathrm{I}^{+}\right)$is $\sim 1 / 3$ of its total concentration. The data for PTHP and anabaseine in Figures 3 and 4 and in Table 1, indicate that PTHP has approximately 30\% of the potency predicted for the anabaseine cyclic iminium form. One possible explanation for this slightly inferior potency is that the additional $\mathrm{N}$ on the tetrahydropyrmidinyl ring must form an $\mathrm{H}$ bond with some other atom within the aromatic box of the nAChR orthosteric binding site and this may be energetically unfavorable.

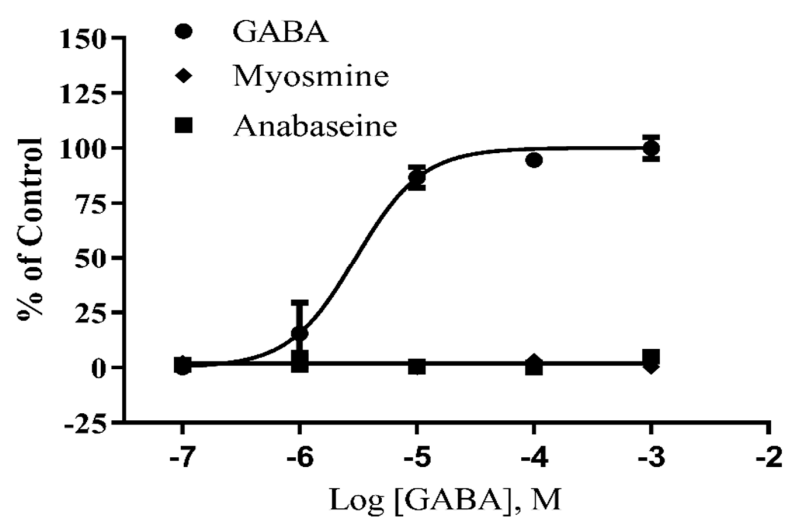

Figure 5. Investigation of possible activation of the human $\mathrm{GABA}_{\mathrm{A}}$ receptor measured by membrane depolarization using a FlexStation assay. Each point is the mean of three separate measurements. All responses were normalized with respect to the response of the cells to $1 \mathrm{mM} \mu \mathrm{M}$ GABA. The EC 50 value for GABA was $3.0 \mu \mathrm{M}(95 \%$ confidence interval = 1.8-5.1 $\mu \mathrm{M})$.

While 2,3'-bipyridyl displayed only a marginal potency at vertebrate receptors that could be predicted from its $\mathrm{pK}_{\mathrm{a}}$, it has been found to be quite paralytic to insects [48] and crustaceans [49,50]. At least some arthropod nAChRs are known to not require a cationic ligand for activation, as shown by many studies with neonicotinoid insecticides such as imidachloprid [37]. These neonicotinoids also display a limited activity at vertebrate $n A C h R s$ [38]. It seems likely that 2,3'-bipyridyl affects some arthropod nAChRs through its unionized form.

One can speculate as to what advantage(s) might accrue to an organism (in this case, a hoplonemertine or ant) to produce and secrete an imine-bond containing toxin like anabaseine. The entire body wall integument as well as the contiguous epithelium of the anterior proboscis of P. peregrina contains very high concentrations of anabaseine [5]. The proboscis everts and wraps around the prey during its capture allowing extensive contact of this epithelium with its annelid prey. The mineralized stylet of the proboscis can be observed to produce multiple punctures of the prey integument, which should further facilitate envenomation. In addition, potential predators will also be exposed in these ways to anabaseine and related alkaloids. Perhaps a major advantage of possessing an imine bond, besides an enhanced affinity for the nAChR orthosteric site [8], is its low basicity, which allows the unionized form to reach a relatively high concentration in the neutral $\mathrm{pH}$ range of the marine environment and thereby enhance passive diffusion across the integument of the prey or predator. The integument of a marine organism exposed to sea water is likely to have a $\mathrm{pH}$ near 8 , well above the $\mathrm{pH}$ range in which anabaseine is primarily ionized. Thus, the toxin has a much better chance of entering the prey/predator than would anabaseine, the more basic secondary amine analog of anabaseine.

Another consideration is how anabaseine is packaged within the venom gland cells [51]. It seems most likely that it is accumulated within secretory vesicles, which are generally acidic ( $\mathrm{pH} \mathrm{5-7).}$ The ionized forms, especially the very polar open-chain forms, would be much less likely to diffuse out of the vesicles than would the cyclic imine form, so their dominance under these acidic conditions should enhance the energy efficiency of anabaseine storage. 
Thus, it is possible that each of the coexisting forms of anabaseine have functional significance, not only for understanding how this potent $\mathrm{nAChR}$ agonist interacts with its receptors, but they also may play different roles in storage and release of the toxin by the nemertine.

We have synthesized other anabaseine compounds whose properties will be reported in the future (Kem et al., in preparation). The current paper predicts that their relative pharmacological potencies will be affected by the extent that the cyclic iminium form dominates the equilibrium between these different forms.

\section{Materials and Methods}

\subsection{Compound Syntheses}

2-(3-pyridyl)-1,4,5,6-tetrahydropyrimidine hydrochloride(PTHP):3-pyridylamidine monohydrochloride $(20 \mathrm{~g}, 0.127 \mathrm{~mol})$ was dissolved in warmed absolute $\mathrm{EtOH}$. To this solution was slowly added (dropwise over $5 \mathrm{~min}$ ) freshly distilled 1,3-diaminopropane $(9.42 \mathrm{~g}, 0.13 \mathrm{~mol})$. This solution was refluxed for $6 \mathrm{~h}$ in a $500 \mathrm{~mL}$ round-bottomed flask. Afterwards the entire solution was placed on a steam bath to dryness. The crude solid was dissolved in approximately $500 \mathrm{~mL}$ hot isopropanol; crystals formed as the solvent was chilled to near $0{ }^{\circ} \mathrm{C}(6.2 \mathrm{~g}, 21.1 \%$ yield, MP 273-275 $)$. Additional recrystallizations from the mother liquor raised the yield. Elemental Analysis: Found: $\% \mathrm{C}=54.71 ; \% \mathrm{H}=6.17 ; \% \mathrm{~N}=21.22 \%$. $\mathrm{C}_{9} \mathrm{H}_{12} \mathrm{~N}_{3} \mathrm{Cl}$ requires: \% $\mathrm{C}=54.69 ; \% \mathrm{H}=6.12 ; \% \mathrm{~N}=21.26$. NMR Spectral data: $\mathrm{In}_{\mathrm{CD}} \mathrm{OD}$, referenced to $\mathrm{CD}_{3} \mathrm{OD}$ at $3.34 \mathrm{ppm}: \delta$ (ppm): 8.85-9.19 $(2 \mathrm{H}, \mathrm{m}, \mathrm{H}-2,6$; 8.23-8.55 $(1 \mathrm{H}, \mathrm{dd}, \mathrm{H}-4) ; 7.85-7.93(1 \mathrm{H}, \mathrm{m}$, $\mathrm{H}-5) ; 4.80\left(2 \mathrm{H}\right.$, broad singlet, $\left.\mathrm{CD}_{3} \mathrm{OH}\right) ; 3.64-3.87\left(4 \mathrm{H}, \mathrm{t} 4,6-\mathrm{CH}_{2}-\right)$; $1.97-2.43\left(2 \mathrm{H}\right.$, quintet, 3- $\mathrm{CH}_{2}-$ ).

3-Pyridylamidine hydrochloride (PTHP Precursor): Our procedure was similar to that described by Schaefer and Peters [52] and Brown and Evans [53]. 3-cyanopyridine ( $35 \mathrm{~g}, 0.34 \mathrm{~mol})$ was dissolved in $300 \mathrm{~mL} \mathrm{MeOH}$ containing sodium methoxide $(1.82 \mathrm{~g}, 0.034 \mathrm{~mol})$. The flask was fitted with a condenser equipped with a drying tube and the clear solution stirred at $25^{\circ} \mathrm{C}$ for $24 \mathrm{~h}$. Ammonium chloride (19.8 g, $0.37 \mathrm{~mol}$ ), added according to and the mixture was refluxed and stirred for $24 \mathrm{~h}$. Not all ( $\sim 30 \%)$ of the ammonium chloride dissolved. After cooling the solution to room temperature and removing excess $\mathrm{NH}_{4} \mathrm{Cl}$ by filtration the resulting solution was rotary evaporated and the product was dissolved in $100 \mathrm{~mL}$ hot isopropanol and filtered hot, leaving the $\mathrm{NH}_{4} \mathrm{Cl}$ behind. After $24 \mathrm{~h}$ at $0{ }^{\circ} \mathrm{C}$ the crystals were collected by filtration. Two more recrystallizations using isopropanol provided a total of 30 g product (MP $187-190{ }^{\circ} \mathrm{C}, 57 \%$ of theoretical yield). Elemental Analysis: Found, $\% \mathrm{C}=$ 45.60; \% $\mathrm{H}=5.17 / \% \mathrm{~N}=26.61 ; \mathrm{C}_{6} \mathrm{H}_{8} \mathrm{~N}_{3} \mathrm{Cl}$ requires: \% $\left.\mathrm{C}=45.73 ; \% \mathrm{H}=5.12 ; \% \mathrm{~N}=26.66\right)$. $\mathrm{NMR}$ Spectral data: $\mathrm{In} \mathrm{CD}_{3} \mathrm{OD}$, referenced to $\mathrm{CD}_{3} \mathrm{OD}$ at $3.34 \mathrm{ppm}: \delta(\mathrm{ppm}): 9.0(2 \mathrm{H}, \mathrm{m}, \mathrm{H}-2, \mathrm{H}-5,6$ coupling of $5 \mathrm{H}$ observed); 8.38-8.63 (1H, dd, $\mathrm{H}-4), \mathrm{H}-4,5$ coupling of $8 \mathrm{~Hz}$ observed, as is $\mathrm{H}-2,4$ coupling of $1.5 \mathrm{~Hz}) ; 7.7-8.0(1 \mathrm{H}, \mathrm{m}, \mathrm{H}-5) ; 5.3\left(\mathrm{CD}_{3} \mathrm{OH}, 4 \mathrm{H}\right.$, broad).

Anabaseine and 5-methylamino-1-(3-pyridyl)-1-pentanone (MAPP) dihydrochlorides (Figure 1) were synthesized as previously reported [31,32]. 2,3'-Bipyridyl was synthesized by silver acetate oxidation of anabaseine obtained from Sigma-Aldrich, St. Louis, MO, USA [49].

\subsection{Radioligand Binding Assays}

$\left[{ }^{3} \mathrm{H}\right]$-carbamylcholine $\left(\left[{ }^{3} \mathrm{H}\right]-\mathrm{MCC}\right)$ binding assays with rat brain membranes were carried out as previously reported with a final concentration of $0.5 \mathrm{nM}\left[{ }^{3} \mathrm{H}\right]-\mathrm{MCC}[8,54] ; 2.8 \mu \mathrm{M}$ atropine sulfate (Sigma-Aldrich) was added to inhibit binding to muscarinic receptors. [ $\left.{ }^{3} \mathrm{H}\right]$-Cytisine and $\left[{ }^{125} \mathrm{I}\right]-\alpha$-bungarotoxin $\left(\left[{ }^{125} \mathrm{I}\right]-\alpha\right.$-BTX) were used in binding experiments with whole rat brain and TE671 cell membranes, respectively, according to Kem et al. [41]. Rat brain membranes (200 $\mu \mathrm{g}$ of protein) on TsA201 cell membranes (100 $\mu$ g protein) expressing human $\alpha 4 \beta 2 \mathrm{nAChRs}$ were incubated with $0.5 \mathrm{nM}\left[{ }^{3} \mathrm{H}\right]$-cytisine in a final volume of $500 \mu \mathrm{L}$ of binding saline for $4 \mathrm{~h}$ at $5^{\circ} \mathrm{C}$. The experiments on $\alpha 7$ nAChRs rat brain membranes involved incubation with $0.5 \mathrm{nM}\left[{ }^{125} \mathrm{I}\right]-\alpha$-Btx for $3 \mathrm{~h}$ at $37^{\circ} \mathrm{C}$ to assure that equilibrium was reached. Eight different concentrations of the experimental compound were usually tested in triplicate. Nonspecific binding was measured in the presence of $1 \mathrm{mM}$ (S)-nicotine hydrogen 
tartrate (Sigma-Aldrich). Data were fitted using GraphPad Prism software (Version 4 GraphPad Software, San Diego, CA, USA) by nonlinear regression analyses to a sigmoidal one-site model with variable slope. Compound affinity for Torpedo electric organ membrane nAChRs was assessed by inhibition of $0.5 \mathrm{nM}\left[{ }^{125} \mathrm{I}\right]-\alpha$-BTX binding over a $30 \mathrm{~min}$ incubation period at $5{ }^{\circ} \mathrm{C}$, since $\alpha$-Btx binds irreversibly to skeletal muscle $\mathrm{nAChRs}$. The $\mathrm{IC}_{50}$ was also estimated by the same Prism software.

\subsection{Cell Culture}

TsA201 cells expressing human $\alpha 4 \beta 2$ were maintained in media consisting of Dulbecco's Modified Eagle medium supplemented with $10 \%$ FBS, 100 units $/ \mathrm{mL}$ penicillin and $100 \mu \mathrm{g} / \mathrm{mL}$ streptomycin, $2 \mathrm{mM}$ L-glutamine, $0.5 \mathrm{mg} / \mathrm{mL}$ zeocin and $0.6 \mathrm{mg} / \mathrm{mL}$ geneticin [55]. Cells were grown in $75 \mathrm{~cm}^{2}$ culture flasks, which were housed in a humidified incubator (Fisher Scientific, Atlanta, GA, USA at $37^{\circ} \mathrm{C}$ in an atmosphere of $5 \% \mathrm{CO}_{2}$. They were grown to around $80-90 \%$ confluence after harvesting with $0.25 \%$ trypsin and being split weekly at a subcultivation ratio of between 1:6 and 1:10.

\subsection{Nicotinic Receptor FlexStation Functional Assays}

Our experimental protocol was based on the initial study of Fitch et al. [56]. Cells were seeded at a density of roughly $5 \times 10^{4}$ to $10^{5}$ cells/well in 96-well flat-bottom black wall culture plates coated with $50 \mu \mathrm{g} / \mathrm{ml}$ poly-D-lysine hydrobromide (Sigma-Aldrich, 70-150 kDa) and grown overnight in $100 \mu \mathrm{L}$ culture medium. A proprietary membrane potential dye obtained from Molecular Devices (San Diego, CA, USA) was prepared by dissolving one bottle of dye into $30 \mathrm{~mL}$ of Hanks Saline ( $\mathrm{pH}=7.4$ ) containing $20 \mathrm{mM}$ HEPES buffer. The cells were incubated with $100 \mu \mathrm{L}$ of dye for $30 \mathrm{~min}$ at $37^{\circ} \mathrm{C}$ prior to the robotically controlled concentration-response experiment. Serial dilutions of a compound for dose-response analysis were prepared in 96-well plates by evaporation of a methanolic stock solution and then reconstituted in the appropriate volume of Hanks saline. Fluid transfer and readings were performed by a FlexStation fluorimeter (Molecular Devices). Excitation and emission wavelengths were set to $530 \mathrm{~nm}$ and $565 \mathrm{~nm}$ with a cutoff of $550 \mathrm{~nm}$. The first $17 \mathrm{~s}$ were used as a basal reading. At $18 \mathrm{~s}$, a test compound was added to determine the $\mathrm{EC}_{50}$, followed by addition of $25 \mu \mathrm{L} \mathrm{KCl}(40 \mathrm{mM}$ final concentration) at $160 \mathrm{~s}$ to serve as a fluorescence calibrant. Compounds that had no measurable depolarizing activity on the TsA201 cells were then tested for their ability to inhibit a $5 \mu \mathrm{M}$ control ACh response. Data were fitted and graphed with Prism (GraphPad) to determine the $\mathrm{EC}_{50}$.

\subsection{GABA Receptor Flexstation Funcional Assays}

WSS1 cells from ATCC (Manassas, VA, USA) which express functional GABA A $_{\text {A }}$ receptors were cultured as previously described by Wong et al. [57]. The cells were grown to near confluence and then transferred to black well, clear bottom 96-well assay plates (Corning Incorporated, Corning, NY, USA) 12-18 h prior to the assay. Molecular Devices blue dye (Sunnyvale, CA, USA) was reconstituted as previously described [58]. The WSS1 cells were allowed to come to room temperature, the culture medium was then aspirated, replaced with the blue dye and equilibrated for $30 \mathrm{~min}$ before being placed on a FlexStation 3 plate reader (Molecular Devices, Sunnyvale, CA, USA). Varying concentrations of $\gamma$-aminobutyric acid (GABA, Tocris Bioscience, Bristol, United Kingdom), myosmine (Sigma, St. Louis, MO, USA) and anabaseine [31,32] in blue dye solution were added to the cells by the FlexStation. Programmed readings and data analysis were performed as previously described [58,59]. The cellular responses to GABA were normalized to the maximum dye response generated by $1 \mathrm{mM}$ GABA. The fifty percent effective concentration for GABA was determined using a sigmoidal dose-response equation (log(agonist) vs. normalized response-Variable slope) with Prism version 6.03 (GraphPad Software, Company, San Diego, CA, USA, www.graphpad.com).

Author Contributions: K.A. carried out the FlexStation assays; H.X. and V.M. carried out radioligand binding assays; B.G. synthesized PTHP; L.B. synthesized compounds (anabaseine, MAPP, DMAPP) and calculated the predicted anabaseine concentrations shown in Figure 2; B.T.G. and S.L. tested anabaseine and myosmine on 
GABA receptor expressing cells; J.L. provided TsA201 cells expressing human $\alpha 4 \beta 2$ nAChRs; W.K. directed the investigation and wrote the manuscript. All authors read and commented on the manuscript.

Funding: This research was funded by Taiho Pharmaceuticals Company (Tokyo) and a Florida Sea Grant (R/LR-MB-20) to W.R. Kem.

Acknowledgments: We greatly appreciate the interest and contributions of our late collaborator John Zoltewicz in the early part of this investigation.

Conflicts of Interest: The authors declare no conflicts of interest.

\section{References}

1. Bacq, Z.M. Les poisons des nemertiens. Bull. Cl. Sci. Acad. R. Belg. 1936, 22, 1072-1079.

2. Bacq, Z.M. L'Amphiporine et La Némertine Poisons Des Vers Némertiens. Arch. Int. Physiol. 1937, 44, $190-204$.

3. King, H. Amphiporine, an active base from the marine worm Amphiporus lactifloreus. J. Chem. Soc. Lond. 1939, 1365.

4. Kem, W.R. A Chemical Investigation of Nemertine Toxins. Ph.D. Thesis, University of Illinois at Urbana-Champaign, Champaign County, IL, USA, 1969; p. 116.

5. Kem, W.R. A study of the occurrence of anabaseine in Paranemertes and other nemertines. Toxicon 1971, 9, 23-32. [CrossRef]

6. Kem, W.R.; Abbott, B.C.; Coates, R.M. Isolation and structure of a hoplonemertine toxin. Toxicon 1971, 9, 15-22. [CrossRef]

7. Wheeler, J.W.; Olubajo, O.; Storm, C.B. Anabaseine: Venom alkaloid of Aphaenogaster ants. Science 1981, 211, 1051-1052. [CrossRef]

8. Kem, W.R.; Mahnir, V.M.; Papke, R.L.; Lingle, C.J. Anabaseine is a potent agonist on muscle and neuronal alpha-bungarotoxin-sensitive nicotinic receptors. J. Pharm. Exp. Ther. 1997, 283, 979-992.

9. Kem, W.R. The brain alpha7 nicotinic receptor may be an important therapeutic target for the treatment of Alzheimer's disease: Studies with DMXBA (GTS-21). Behav. Brain Res. 2000, 113, 169-183. [CrossRef]

10. Slavov, S.H.; Radzvilovits, M.; LeFrancois, S.; Stoyanova-Slavova, I.B.; Soti, F.; Kem, W.R.; Katritzky, A.R. A computational study of the binding of 3-(arylidene) anabaseines to two major brain nicotinic acetylcholine receptors and to the acetylcholine binding protein. Eur. J. Med. Chem. 2010, 45, 2433-2446. [CrossRef]

11. Kem, W.; Soti, F.; Wildeboer, K.; LeFrancois, S.; MacDougall, K.; Wei, D.-Q.; Chou, K.-C.; Arias, H. The nemertine toxin anabaseine and its derivative DMXBA (GTS-21): Chemical and pharmacological properties. Mar. Drugs 2006, 4, 255-273. [CrossRef]

12. Freedman, R.; Olincy, A.; Buchanan, R.W.; Harris, J.G.; Gold, J.M.; Johnson, L.; Allensworth, D.; Guzman-Bonilla, A.; Clement, B.; Ball, M.P.; et al. Initial phase 2 trial of a nicotinic agonist in schizophrenia. Am. J. Psychiatry 2008, 165, 1040-1047. [CrossRef]

13. Kem, W.R.; Olincy, A.; Johnson, L.; Harris, J.; Wagner, B.D.; Buchanan, R.W.; Christians, U.; Freedman, R. Pharmacokinetic Limitations on Effects of an Alpha7-Nicotinic Receptor Agonist in Schizophrenia: Randomized Trial with an Extended-Release Formulation. Neuropsychopharmacology 2018, 43, 583-589. [CrossRef]

14. Pavlov, V.A.; Ochani, M.; Yang, L.H.; Gallowitsch-Puerta, M.; Ochani, K.; Lin, X.; Levi, J.; Parrish, W.R.; Rosas-Ballina, M.; Czura, C.J.; et al. Selective alpha7-nicotinic acetylcholine receptor agonist GTS-21 improves survival in murine endotoxemia and severe sepsis. Crit. Care Med. 2007, 35, 1139-1144. [CrossRef]

15. Kashiwagi, S.; Khan, M.A.; Yasuhara, S.; Goto, T.; Kem, W.R.; Tompkins, R.G.; Kaneki, M.; Martyn, J.A. Prevention of burn-induced inflammatory responses and muscle wasting by GTS-21, a specific agonist for $\alpha 7$ nicotinic acetylcholine receptors. Shock 2017, 47, 61-69. [CrossRef]

16. Schaller, S.J.; Nagashima, M.; Schönfelder, M.; Sasakawa, T.; Schulz, F.; Khan, M.A.S.; Kem, W.R.; Schneider, G.; Schlegel, J.; Lewald, H.; et al. GTS-21 attenuates loss of body mass, muscle mass, and function in rats having systemic inflammation with and without disuse atrophy. Pflüg. Arch. Eur. J. Physiol. 2018, 470, 1647-1657. [CrossRef]

17. Suzuki, S.; Kawamata, J.; Matsushita, T.; Matsumura, A.; Hisahara, S.; Takata, K.; Kitamura, Y.; Kem, W.R.; Shimohama, S. 3-[(2,4-Dimethoxy) benzylidene]-anabaseine dihydrochloride prevents 6-hydroxydopamine-induced Parkinsonism neurodegeneration through $\alpha 7$ nicotinic acetylcholine receptor stimulation in rats. J. Neurosci. Res. 2012, 91, 462-471. [CrossRef] 
18. Takata, K.; Amamiya, T.; Mizoguchi, H.; Kawanishi, S.; Kuroda, E.; Kitamura, R.; Ito, A.; Saito, Y.; Tawa, M.; Nagasawa, T.; et al. Alpha7 nicotinic acetylcholine receptor-specific agonist DMXBA (GTS-21) attenuates A $\beta$ accumulation through suppression of neuronal $\gamma$-secretase activity and promotion of microglial amyloid- $\beta$ phagocytosis and ameliorates cognitive impairment in a mouse model of Alzheimer's disease. Neurobiol. Aging 2018, 62, 197-209.

19. Kem, W.R.; Soti, F. Alpha7 Nicotinic Receptor Selective Ligands. U.S. Patent 8,592,458, 14 December 2006.

20. Kem, W.R.; Soti, F.; Xing, H. Bicyclic Tetrahydropyridyl Alpha7 Selective Agonists. U.S. Patent 9,150,558, 6 October 2015.

21. Changeux, J.P. The nicotinic acetylcholine receptor: The founding father of the pentameric ligand-gated ion channel superfamily. J. Bio. Chem. 2012, 287, 40207-40215. [CrossRef]

22. Brejc, K.; van Dijk, W.J.; Klaassen, R.V.; Schuurman, M.; van Der Oost, J.; Smit, A.B.; Sixma, T.K. Crystal structure of an ACh-binding protein reveals the ligand-binding domain of nicotinic receptors. Nature 2001, 411, 269-276. [CrossRef]

23. Barlow, R.B.; Hamilton, J.T. Effects of $\mathrm{pH}$ on the activity of nicotine and nicotine monomethiodide on the rat diaphragm preparation. Br. J. Pharmacol. Chemother. 1962, 18, 543-549. [CrossRef]

24. Hamilton, J.T. The influence of $\mathrm{pH}$ on the activity of nicotine at the neuromuscular junction. Can. J. Biochem. Physiol. 1963, 41, 283-289. [CrossRef] [PubMed]

25. Bartels, E.; Podleski, T.R. Action of nicotine on the electroplax and difference of potency between ionized and unionized forms. Biochim. Biophys. Acta 1964, 79, 511-520. [CrossRef]

26. Palma, A.; Li, L.; Chen, X.; Pappone, P.; McNamee, M. Effects of $\mathrm{pH}$ on acetylcholine receptor function. J. Membr. Biol. 1991, 120, 67-73. [CrossRef]

27. Abdrakhamanova, G.; Cleemann, L.; Lindstrom, J.; Morad, M. Differential modulation of $\beta 2$ and $\beta 4$ subunits of human neuronal nicotinic acetylcholine receptors by acidification. Mol. Pharmacol. 2004, 66, 347-355. [CrossRef]

28. Hutter, O.F.; Warner, A.E. The $\mathrm{pH}$ sensitivity of the chloride conductance of frog skeletal muscle. J. Physiol. 1967, 189, 403-425. [CrossRef]

29. Mallart, A.; Trautmann, A. Ionic properties of the neuromuscular junction of the frog: Effects of denervation and pH. J. Physiol. 1973, 234, 553-567. [CrossRef]

30. Yamamoto, I.; Kamimura, H.; Yamamoto, R.; Sakai, S.; Goda, M. Studies on nicotinoids as insecticides. Pt. I. Relation of structure to toxicity. Agric. Biol. Chem. 1962, 26, 709-716.

31. Zoltewicz, J.A.; Bloom, L.B.; Kem, W.R. Quantitative determination of the ring-chain hydrolysis equilibrium constant for anabaseine and related tobacco alkaloids. J. Org. Chem. 1989, 54, 4462-4468. [CrossRef]

32. Bloom, L.B. Influence of Solvent on the Ring-Chain Hydrolysis Equilibrium of Anabaseine and Syntheses of Anabaseine and Nicotine Analogs. Ph.D. Thesis, University of Florida, Gainesville, FL, USA, 1990; p. 207.

33. Zoltewicz, J.A.; Bloom, L.B.; Kem, W.R. Hydrolysis of cholinergic anabaseine and N-methylanabaseine: Influence of cosolvents on the position of the ring-chain equilibrium-compensatory changes. Bioorg. Chem. 1990, 18, 395-412. [CrossRef]

34. Krumholz, P. Structural studies on polynuclear pyridine compounds. J. Am. Chem. Soc. 1951, 73, 3487-3492. [CrossRef]

35. Green, B.T.; Goulart, C.; Welch, K.D.; Pfister, J.A.; McCollum, I.; Gardner, D.R. The non-competitive blockade of $\mathrm{GABA}_{\mathrm{A}}$ receptors by an aqueous extract of water hemlock (Cicuta douglasii) tubers. Toxicon 2015, 108, 11-14. [CrossRef]

36. Culver, P.; Fenical, W.; Taylor, P. Lophotoxin irreversibly inactivates the nicotinic acetylcholine receptor by preferential association at one of the two primary agonist sites. J. Biol. Chem. 1984, 259, 3763-3770.

37. Tomizawa, M.; Casida, J.E. Molecular recognition of neonicotinoid insecticides: The determinants of life or death. Acc. Chem. Res. 2009, 42, 260-269. [CrossRef]

38. Li, P.; Ann, J.; Akk, G. Activation and modulation of human alpha4beta2 nicotinic acetylcholine receptors by the neonicotinoids clothianidin and imidacloprid. J. Neurosci. Res. 2009, 89, 1295-1301. [CrossRef]

39. Kaczanowska, K.; Camacho Hernandez, G.A.; Bendiks, L.; Kohs, L.; Cornejo-Bravo, J.M.; Harel, M.; Finn, M.G.; Taylor, P. Substituted 2-aminopyrimidines selective for $\alpha 7$-nicotinic acetylcholine receptor activation and association with acetylcholine binding proteins. J. Am. Chem. Soc. 2017, 139, 3676-3684. [CrossRef]

40. Kem, W.R. Biochemistry of Nemertine Toxins. In Marine Pharmacognosy: Marine Biotoxins as Probes of Cellular Function; Martin, D.F., Padilla, G.M., Eds.; Academic Press: New York, NY, USA, 1973; pp. 37-84. 
41. Kem, W.R.; Mahnir, V.M.; Prokai, L.; Papke, R.L.; Cao, X.; LeFrancois, S.; Wildeboer, K.; Prokai-Tatrai, K.; Porter-Papke, J.; Soti, F. Hydroxy metabolites of the Alzheimer's drug candidate 3-[(2,4-dimethoxy)benzylidene]-anabaseine dihydrochloride (GTS-21): Their molecular properties, interactions with brain nicotinic receptors, and brain penetration. Mol. Pharmacol. 2004, 6, 56-67. [CrossRef]

42. Zoltewicz, J.A.; Prokai-Tatrai, K.; Bloom, L.B.; Kem, W.R. Long range transmission of polar effects of cholinergic 3-arylideneanabaseines, Conformations calculated by molecular modelling. Heterocycles 1993, 35, 171-179. [CrossRef]

43. Mallipeddi, P.L.; Pedersen, S.E.; Briggs, J.M. Interactions of acetylcholine binding site residues contributing to nicotinc acetylcholine receptor gating: Role of residues Y93, Y190, K145 and D200. J. Mol. Gr. Model. 2013, 44, 145-154. [CrossRef]

44. Hibbs, R.E.; Sulzenbacher, G.; Shi, J.; Talley, T.T.; Kem, W.R.; Marchot, P.; Taylor, P.; Bourne, Y. Structural determinants for interaction of partial agonists with acetylcholine binding protein and neuronal $\alpha 7$ nicotinic acetylcholine receptor. EMBO J. 2009, 28, 3040-3051. [CrossRef]

45. Brimblecombe, R.E.; Hunt, R.R.; Rickard, R.L.; Taylor, J.V. The synthesis and pharmacology of some 1,4,5,6-tetrahydropyrimidines. Br. J. Pharmacol. 1969, 37, 425-435. [CrossRef]

46. Upshall, D.G. Correlation of chick embryo teratogenicity with the nicotinic activity of a series of tetrahydropyrimidines. Teratology 1972, 5, 287-294. [CrossRef] [PubMed]

47. Woodruff, G.N.; Walker, R.J.; Newton, L.C. Actions of some muscarinic and nicotinic agonists on the Retzius cells of the leech. Comp. Gen. Pharmacol. 1971, 2, 106-117. [CrossRef]

48. Smith, C.R.; Richardson, C.H.; Shepard, H.H. Neonicotine and certain other derivatives of the dipyridyls as insecticides. J. Econ. Entomol. 1930, 23, 863-870. [CrossRef]

49. Kem, W.R.; Scott, K.N.; Duncan, J.H. Hoplonemertine worms-A new source of pyridine neurotoxins. Experientia 1976, 32, 684-686. [CrossRef] [PubMed]

50. Kem, W.R.; Soti, F.; Rittschof, D. Inhibition of barnacle larval settlement and crustacean toxicity of some hoplonemertine pyridyl alkaloids. Biomol. Eng. 2003, 20, 355-361. [CrossRef]

51. Stricker, S.A.; Cloney, R.A. The ultrastructure of venom-producing cells in Paranemertes peregrina (Nemertea, Hoplonemertea). J. Morphol. 1983, 177, 89-107. [CrossRef]

52. Schaefer, F.C.; Peters, G.A. Base-catalyzed reaction of nitriles with alcohols. A convenient route to imidates and amidine salts. J. Org. Chem. 1960, 26, 412. [CrossRef]

53. Brown, D.J.; Evans, R.F. Hydropyrimidines. Part II. A new general synthesis of substituted 1,4,5,6-tetrahydropyridines. J. Chem. Soc. 1962, 4039. [CrossRef]

54. Boksa, P.; Quirion, R. $\left[{ }^{3} \mathrm{H}\right]$-methyl-carbamylcholine, a new radioligand specific for nicotinic acetylcholine receptors in brain. Eur. J. Pharmacol. 1987, 139, 323-333. [CrossRef]

55. Kuryatov, A.; Luo, J.; Cooper, J.; Lindstrom, J. Nicotine acts as a pharmacological chaperone to upregulate human alpha4 beta2 acetylcholine receptors. Mol. Pharmacol. 2005, 68, 1839-1851. [CrossRef]

56. Fitch, R.W.; Xiao, Y.; Kellar, K.J.; Daly, J.W. Membrane potential fluorescence: A rapid and highly sensitive assay for nicotinic receptor channel function. Proc. Natl. Acad. Sci. USA 2003, 100, 4909-4914. [CrossRef] [PubMed]

57. Wong, G.; Sei, Y.; Skolnick, P. Stable expression of type I gamma-aminobutyric acidA/benzodiazepine receptors in a transfected cell line. Mol. Pharmacol. 1992, 42, 996-1003. [PubMed]

58. Green, B.T.; Lee, S.T.; Panter, K.E.; Welch, K.D.; Cook, D.; Pfister, J.A.; Kem, W.R. Actions of piperidine alkaloid teratogens at fetal nicotinic acetylcholine receptors. Neurotoxicol. Teratol. 2010, 32, 383-389. [CrossRef] [PubMed]

59. Lee, S.T.; Wildeboer, K.; Panter, K.E.; Kem, W.R.; Gardner, D.R.; Molyneux, R.J.; Chang, S.-W.T.; Soti, F.; Pfister, J.A. Relative toxicities and neuromuscular nicotinic receptor agonistic potencies of anabaseine enantiomers and anabaseine. Neurotoxicol. Teratol. 2006, 28, 220-228.

(C) 2019 by the authors. Licensee MDPI, Basel, Switzerland. This article is an open access article distributed under the terms and conditions of the Creative Commons Attribution (CC BY) license (http://creativecommons.org/licenses/by/4.0/). 